\title{
Conservation characteristics of corn ears and stover ensiled with the addition of Lactobacillus plantarum MTD-1, Lactobacillus plantarum 30114, or Lactobacillus buchneri 11A44
}

\author{
J. P. Lynch, ${ }^{*}$ P. O’Kiely, ${ }^{\star 1}$ S. M. Waters, ${ }^{*}$ and E. M. Doyle† \\ *Animal and Grassland Research and Innovation Centre, Teagasc, Grange, Dunsany, Co. Meath, Ireland \\ †School of Biology and Environmental Science, University College Dublin, Belfield, Dublin 4, Ireland
}

\begin{abstract}
The aim of this study was to investigate the effects of inoculating 3 contrasting lactic acid bacteria on the fermentation profile, estimated nutritive value, and aerobic stability of corn ears and stover produced under marginal growing conditions. Ears and stover were separated from whole-crop corn plants obtained from 3 replicate field blocks. Representative subsamples were precision chopped and allocated to 1 of the following treatments: an uninoculated control, Lactobacillus plantarum MTD-1 (LP1), L. plantarum 30114 (LP2), or Lactobacillus buchneri 11A44 (LB). Each bacterial additive was applied at a rate of $1 \times 10^{6} \mathrm{cfu} / \mathrm{g}$ of fresh herbage. Triplicate samples of each treatment were ensiled in laboratory silos at $15^{\circ} \mathrm{C}$ for $3,10,35$, or 130 d. No difference was observed between the dry matter recoveries of uninoculated ear or stover silages and silages made with LP1, and the aerobic stability of uninoculated ear and stover silages did not differ from silages made with LB. Stover silages made with LP2 and ensiled for $35 \mathrm{~d}$ had a lower proportion of lactic acid in total fermentation products compared with LP1. The aerobic stability and dry matter recovery of ear and stover silages in this study were not improved when made with LB, LP1, or LP2, due to the indigenous highly heterolactic fermentation that prevailed in the uninoculated ear and stover during 130-d ensilage.
\end{abstract}

Key words: ear, stover, additive, silage

\section{INTRODUCTION}

Consistently satisfactory yields of corn of high nutritive value followed by ensilage practices that result in minimal conservation losses are required in climatically marginal areas such as Ireland to sustain the economic viability of this crop. Substantial losses of DM yield and nutritive value can occur during and after the ensi-

Received October 3, 2011.

Accepted November 26, 2011.

${ }^{1}$ Corresponding author: padraig.okiely@teagasc.ie lage of whole-crop corn as a result of fermentation and respiration by undesirable microorganisms (McDonald et al., 1991). The use of bacterial inoculants at ensiling, selected to dominate the epiphytic bacteria on the herbage and alter the fermentation process, can successfully reduce the losses in yield and nutritive value associated with silage production (Muck, 2010).

Fermentation-related losses occur during ensilage due to the inefficient degradation of fermentable substrate by undesirable microorganisms (e.g., clostridia and enterobacteria), producing gas that is lost to the atmosphere and products, such as butyric acid, which are associated with a reduction in the nutritive value (McDonald et al., 1991). Bacterial inoculants that promote highly efficient lactic acid-dominated fermentations, such as those based on Lactobacillus plantarum, have the potential to increase lactic acid production by the homofermentative utilization of hexose sugars in the early stages of ensilage. This causes a quick decline in $\mathrm{pH}$ and the creation of a more inhibitory environment for many undesirable microorganisms (Hu et al., 2009; Filya and Sucu, 2010).

Aerobic losses in silages are generally initiated by the respiration of substrate by yeast to produce gas, heat, and water (Muck, 2010). This aerobic deterioration is lower in silages with higher concentrations of antifungal compounds, such as acetic acid and propionic acid. Therefore, inoculating with bacteria (e.g., Lactobacillus buchneri) that promote the production of these compounds in the silo have the potential to increase the aerobic stability of whole-crop corn silage (Ranjit and Kung, 2000; Driehuis et al., 2001; Schmidt and Kung, 2010).

Corn plants consist of 2 physical components with contrasting chemical compositions: the starch-rich ear (grain and rachis) and the fiber-rich stover (stem, leaves, husks, and tassel), with the proportion of these components changing as the plant matures (Phipps and Weller, 1979). Research into the ensilage of these individual components is important, as the proportion of ear or stover in whole-crop corn can vary considerably in marginal growing areas. Studies investigating 
Table 1. Mean (SD) chemical composition of corn ears and stover at harvest ${ }^{1}$

\begin{tabular}{|c|c|c|}
\hline Item & Ear & Stover \\
\hline $\begin{array}{l}\text { Proportion of whole crop (g of component } / \mathrm{kg} \text { of whole plant) } \\
\text { DM }(\mathrm{g} / \mathrm{kg}) \\
\mathrm{DMD}^{2}(\mathrm{~g} / \mathrm{kg}) \\
\mathrm{WSC}^{3}(\mathrm{~g} / \mathrm{kg} \text { of } \mathrm{DM}) \\
\mathrm{Starch}(\mathrm{g} / \mathrm{kg} \text { of } \mathrm{DM}) \\
\mathrm{NDF}(\mathrm{g} / \mathrm{kg} \text { of } \mathrm{DM}) \\
\mathrm{CP}(\mathrm{g} / \mathrm{kg} \text { of } \mathrm{DM}) \\
\text { Ash }(\mathrm{g} / \mathrm{kg} \text { of } \mathrm{DM}) \\
\text { Buffering capacity }(\mathrm{mEq} / \mathrm{kg} \text { of } \mathrm{DM}) \\
\mathrm{LAB}^{5}\left[\log _{10}(\mathrm{cfu} / \mathrm{g} \text { of herbage })\right]\end{array}$ & $\begin{aligned} 329 & (45.5) \\
428 & (5.4) \\
739 & (22.5) \\
65 & (7.4) \\
518 & (21.4) \\
291 & (25.5) \\
63 & (0.8) \\
68 & (6.4) \\
136 & (5.5) \\
5.46 & (0.302)\end{aligned}$ & $\begin{aligned} & 671(45.5) \\
& 189(9.3) \\
& 665(11.2) \\
& 64(11.1) \\
& \mathrm{ND}^{4} \\
& 741(21.7) \\
& 71(1.0) \\
& 68(4.1) \\
& 319(21.0) \\
& 6.10(0.626)\end{aligned}$ \\
\hline $\begin{array}{l}{ }^{1} \text { Three replicates analyzed per mean. } \\
{ }^{2} \text { DM digestibility. } \\
{ }^{3} \text { Water-soluble carbohydrates. } \\
{ }^{4} \text { Not determined. } \\
{ }^{5} \text { Lactic acid bacteria. }\end{array}$ & & \\
\hline
\end{tabular}

the ensilage of the ear have reported substantial aerobic deterioration (Phillip et al., 1985) but the use of heterofermentative lactic acid bacteria (LAB) inoculants has been reported to improve the aerobic stability of these silages (Taylor and Kung, 2002; Kung et al., 2007). However, information on the effects of bacterial inoculants on the ensilage of the ear and stover components of a crop produced in marginal growing areas is not available. The aim of this study was to investigate the effects of inoculating corn ears and stover produced in a marginal growing area with 3 different LAB on the fermentation profile, nutritive value, and aerobic stability of the subsequent silage.

\section{MATERIALS AND METHODS}

Triplicate samples of ears and stover were allocated to 1 of 4 additive treatments and ensiled in laboratory-scale silos for 1 of 4 durations of ensilage $(\mathrm{n}=$ 96 samples). The fermentation profiles of silages were investigated after each ensiling duration, whereas the estimated nutritive value and aerobic stability were assessed after only $130 \mathrm{~d}$ ensilage. In addition, LAB plate counts, and real-time quantitative PCR (qPCR) were carried out at each time point to estimate L. plantarum and L. buchneri population sizes.

\section{Forage Preparation}

Crops of Andante (Groupe Limagrain, Chappes, France) cultivar of corn were grown under plastic mulch at Grange, Dunsany, Co. Meath, Ireland $\left(53^{\circ} 30^{\prime} \mathrm{N}\right.$, $6^{\circ} 39^{\prime} \mathrm{W}$ and $83 \mathrm{~m}$ above sea level) during 2009. The total Ontario heat units (OHU) and the average daily rainfall between sowing and harvesting the crop were $2,095 \mathrm{OHU}$ and $3.3 \mathrm{~mm} / \mathrm{d}$, respectively. On October 13, 2009, for each of 3 replicate blocks, 6 central rows of an 8 row plot of corn plants were harvested using a reciprocating blade mower [Agria $5400 \mathrm{KL}$; Agria (UK) Ltd., Nottingham, UK] to a stubble height of $10 \mathrm{~cm}$. Ears (grain and rachis) and stover (stem, leaves, husks, and tassels) were separated by hand and subsequently precision chopped using a food processor (MTK 204 special; Müller, Saarbrücken, Germany) or precision-chop harvester (Pöttinger Mex VI; Pöttinger, Grieskirchen, Austria), respectively. The chemical compositions of ears and stover at ensiling are reported in Table 1.

\section{Inoculant Preparation and Ensilage}

Three sources of LAB were used in this study (Table 2 ). Each had a target application rate of $1 \times 10^{6} \mathrm{cfu} / \mathrm{g}$ fresh herbage, with application rates confirmed by plating on de Man, Rogosa, and Sharpe (MRS) agar (CM361B; Oxoid Ltd., Cambridge, UK). The inoculants were applied evenly to the herbage in a suspension with distilled water at a rate of $4 \mathrm{~mL} / \mathrm{kg}$ of fresh herbage. The control herbages did not receive any distilled water application. Aseptic procedures were applied throughout additive preparation, application, ensiling, and sampling to prevent any cross contamination between treatments. Samples (6 kg of herbage, excluding additive) of ears and stover were ensiled in laboratory silos (height, $0.75 \mathrm{~m}$; i.d., $0.152 \mathrm{~m}$; internal volume $13.6 \mathrm{~L}$; O'Kiely and Wilson, 1991) and stored at approximately $15^{\circ} \mathrm{C}$ for either $3,10,35$, or 130 d. Samples for chemical or molecular analyses were taken immediately pre- and post-ensiling and stored at $-20^{\circ} \mathrm{C}$, whereas unfrozen samples were used for conventional microbial analysis. Effluent (if any) and silage were weighed at silo opening.

\section{Chemical Analysis}

Samples of stover were further homogenized using a food processor before chemical composition analysis. 
Table 2. Species, sources, and abbreviations of bacterial additives used in the study

\begin{tabular}{lll}
\hline Bacterium & Source & Abbreviation \\
\hline Lactobacillus buchneri 11A44 & Pioneer Hi-Bred International Inc., IA & LB \\
Lactobacillus plantarum MTD-1 & Ecosyl Products Ltd., Yorkshire, UK & LP1 \\
L. plantarum 30114 & Ecosyl Products Ltd., Yorkshire, UK & LP2 \\
\hline
\end{tabular}

The DM concentration of the pre-ensiling ear and stover samples was determined by drying in an oven with forced-air circulation at $98^{\circ} \mathrm{C}$ for $16 \mathrm{~h}$, whereas the corresponding post-ensilage samples were dried at $85^{\circ} \mathrm{C}$ for $16 \mathrm{~h}$ and corrected for loss of volatiles using the equation of Porter and Murray (2001). Pre-ensiled samples and samples taken after $130 \mathrm{~d}$ of ensilage were oven-dried at $40^{\circ} \mathrm{C}$ for $48 \mathrm{~h}$, milled (Wiley mill, 1-mm screen; Thomas Scientific, Swedesboro, NJ) and used for the determination of in vitro DM digestibility (DMD), starch, cold water-soluble carbohydrates (WSC), CP, NDF, and ash contents, as well as buffering capacity. The DMD was determined by the method of Tilley and Terry (1963), but with the final residue isolated by filtration (through Whatman GF A filters, pore size $1.6 \mu \mathrm{m}$; Whatman International Ltd., Maidstone, UK) rather than centrifugation. Starch content was determined using the Megazyme total starch assay procedure (McCleary et al., 1994). The concentration of WSC was determined using the automated anthrone method (Thomas, 1977) and CP [total nitrogen $(\mathrm{N}) \times$ $6.25]$ was determined using a Leco FP-528N analyzer (Leco Corp., St. Joseph, MI) by measuring the thermal conductivity of $\mathrm{N}$ present in a sample, following total combustion at $900^{\circ} \mathrm{C}$, based on the methods of the Association of Official Analytical Chemists (AOAC, 1990; method 900-03). The NDF concentration was analyzed using the Ankom filter bag (Ankom Technology, Macedon, NY) technique based on the analytical method of Van Soest et al. (1991), with the inclusion of heattolerant $\alpha$-amylase and sodium sulfite and expressed on an ash-free basis. Ash concentration was determined by complete combustion in a muffle furnace at $550^{\circ} \mathrm{C}$ for 5 h. Buffering capacity was analyzed using the method of Playne and McDonald (1966).

Aqueous extracts were removed from all silage samples using a hydraulic press. Silage $\mathrm{pH}$ was determined using a pH electrode (HI98127; Hanna Instruments Ltd., Leighton Buzzard, Bedfordshire, UK). Volatile fatty acids and ethanol concentrations were measured using a gas chromatograph (GC 17-A; Milton Shimadzu UK Ltd., Milton Keynes, UK) with a flame ionization detector and fitted with a Chrompack glass column $(2.4 \mathrm{~m} \times 5 \mathrm{~mm}$ o.d. $\times 3 \mathrm{~mm}$ i.d. with $\mathrm{T} \max$ $200^{\circ} \mathrm{C}$ packed with $9 \% \mathrm{CW} 20-\mathrm{M}, 1 \% \mathrm{H}_{3} \mathrm{PO}_{4}$ on Chrom WAP 80-100 mesh; Varian Inc., Palo Alto, CA) by the method of Ranfft (1973). Lactic acid concentration was determined using the SP-Ace Clinical Chemical Analyzer, (Alfa Wassermann Inc., West Caldwell, NJ) and the L-lactic acid UV-method test kit (catalog number 101309084035; Roche/R-Biopharm, Darmstadt, Germany), whereas D-lactate concentration was determined using the enzyme D-lactate dehydrogenase (catalog number 1016941001; Roche/R-Biopharm). The concentration of ammonia $\left(\mathrm{NH}_{3}\right)$ was determined using the SP-Ace Clinical Chemical Analyzer and the Thermo Electron Infinity ammonia liquid stable reagent kinetic method (Thermo Fisher Scientific Inc., Waltham, MA).

\section{Conventional Microbial Analysis}

Fresh-crop and silage samples were initially stored at $4^{\circ} \mathrm{C}$ with the isolation of microbes from the herbage commencing within $4 \mathrm{~h}$ of harvesting or silo opening, respectively. A $30-\mathrm{g}$ sample of herbage was added to 270 $\mathrm{mL}$ of peptone water $\left(1 \mathrm{~g} / \mathrm{L}\right.$ of distilled $\mathrm{H}_{2} \mathrm{O}$; LP0037; Oxoid Ltd.) in sterile stomacher bags and homogenized for $3 \mathrm{~min}$ in a stomacher laboratory blender (Colworth stomacher 400; Seward Ltd., Sussex, UK). Serial 10-fold dilutions were then made with peptone water. Medium consisting of MRS agar (CM 361; Oxoid Ltd.) and nystatin (100,000 units; N1638; Sigma-Aldrich Ltd., Wicklow, Ireland) agar was used for the enumeration of LAB using the double-layer pour plate technique. After incubation at $30^{\circ} \mathrm{C}$ for $72 \mathrm{~h}$, the colony-forming units on each plate were enumerated and the number of LAB, expressed per gram of herbage on a $\log _{10}$ basis, was determined.

\section{Total DNA Extraction}

Total DNA was extracted from herbage samples based on the method described by Schmidt et al. (2008). Briefly, a 20-g subsample of herbage was added to 180 $\mathrm{mL}$ of one-quarter-strength Ringers solution (BR0052; Oxoid Ltd.) in sterile stomacher bags and homogenized in a stomacher laboratory blender for $3 \mathrm{~min}$. A $1-\mathrm{mL}$ aliquot was then pelleted by centrifugation $(16,000 \times g)$ and resuspended in $400 \mu \mathrm{L}$ of TES buffer $(50 \mathrm{mmol} / \mathrm{L}$ of Tris-HCL; $1 \mathrm{mmol} / \mathrm{L}$ of EDTA; $6.7 \%$ glucose). Cell lysis was initiated through incubation with $25 \mu \mathrm{L}$ of lysozyme (10 mg/mL; 62970; Sigma-Aldrich Ltd.) and 
$7.5 \mu \mathrm{L}$ of mutanolysin $\left(1,000\right.$ units/mL of $\mathrm{H}_{2} \mathrm{O}$; M9901; Sigma-Aldrich Ltd.) at $37^{\circ} \mathrm{C}$ for $30 \mathrm{~min}$, and a subsequent 16 -h incubation with $15 \mu \mathrm{L}$ of proteinase $\mathrm{K}$ (20 mg/mL; P2308; Sigma-Aldrich Ltd.) and $40 \mu \mathrm{L}$ of SDS (200 mg/mL; L4390; Sigma-Aldrich Ltd.). Samples were purified using a phenol:chloroform:isoamyl alcohol (25:24:1; 77617; Sigma-Aldrich Ltd.) extraction and the eluted DNA was precipitated overnight at $-20^{\circ} \mathrm{C}$ with ethanol and $4 \mathrm{~mol} / \mathrm{L}$ of sodium acetate. The DNA was pelleted, washed with ethanol, air dried, and resuspended in $50 \mu \mathrm{L}$ of TE buffer $(10 \mathrm{mM}$ Tris, $1 \mathrm{mM}$ EDTA; 93283; Sigma-Aldrich Ltd.). The yield (mean $61 \mathrm{ng} / \mu \mathrm{L})$ and purity $\left(A_{260}: A_{280}\right.$; mean 1.65$)$ of DNA extracted was determined using a NanoDrop ND-1000 (NanoDrop Technologies Inc., Wilmington, DE).

\section{Real-Time $q P C R$}

Primers used for species specific quantification of L. buchneri and L. plantarum were commercially synthesized (Table 3; Sigma-Aldrich Ltd.). The qPCR reactions were performed in triplicate using an Applied Biosystems Fast 7500 v2.0.1 instrument (Applied Biosystems, Dublin, Ireland) with the following cycling parameters: $95^{\circ} \mathrm{C}$ for $20 \mathrm{~s}, 40$ cycles of $95^{\circ} \mathrm{C}$ for $3 \mathrm{~s}$, $60^{\circ} \mathrm{C}$ for $30 \mathrm{~s}$, followed by amplicon dissociation $\left(95^{\circ} \mathrm{C}\right.$ for $15 \mathrm{~s}, 60^{\circ} \mathrm{C}$ for $60 \mathrm{~s}, 95^{\circ} \mathrm{C}$ for $15 \mathrm{~s}$, and $60^{\circ} \mathrm{C}$ for 15 $\mathrm{s})$. The reaction mixture contained $10 \mu \mathrm{L}$ of Fast SYBR Green master mix (Applied Biosystems), $1 \mu \mathrm{L}$ of the forward and reverse primers $(20 \mathrm{mmol} / \mathrm{L}), 8 \mu \mathrm{L}$ of $\mathrm{H}_{2} \mathrm{O}$ and $1 \mu \mathrm{L}$ of template DNA $(10 \mathrm{ng} / \mu \mathrm{L})$. Dissociation curves were examined for the presence of a single PCR product. The efficiency $(\boldsymbol{E})$ of the qPCR reaction was calculated using a 10-fold serial dilution of template DNA and the generation of a standard curve. The slope of the curve was entered into the calculation $E=10^{-1 /}$ slope.

\section{Standard Curve Construction}

For estimation of L. buchneri and L. plantarum population sizes in corn ear and stover silage samples, a standard curve was constructed, plotting known quantities of the bacteria, determined from pour plating the inoculants using MRS agar as described earlier, against the cycle threshold $\left(\mathrm{C}_{\mathrm{T}}\right)$ values obtained from the species-specific quantification using qPCR. Samples of straw were inoculated to obtain a range of $10^{3}, 10^{4}$, $10^{5}, 10^{6}, 10^{7}$, and $10^{8} \mathrm{cfu}$ of each bacteria per gram of herbage. After 1-h incubation at $20^{\circ} \mathrm{C}$, total DNA was extracted as described above and analyzed using qPCR. The standard curve was constructed using Microsoft Excel 2003 and the numbers of L. buchneri and L. plantarum are presented as colony-forming unit

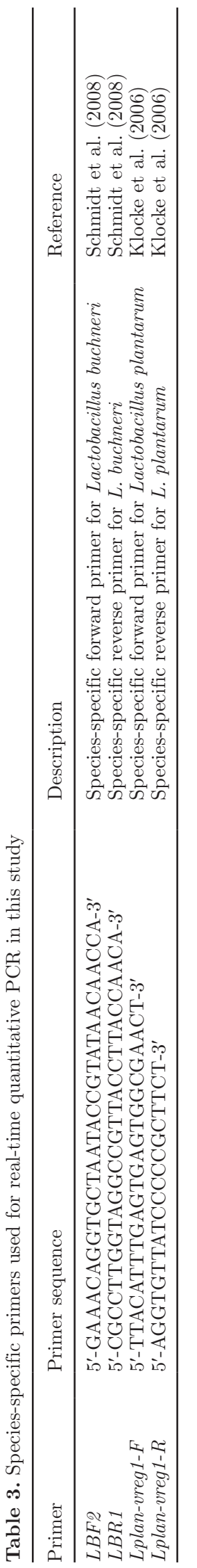

Journal of Dairy Science Vol. 95 No. 4, 2012 
Table 4. The effect of bacterial additives on corn ear and stover silage nutritive quality after 130-d ensilage

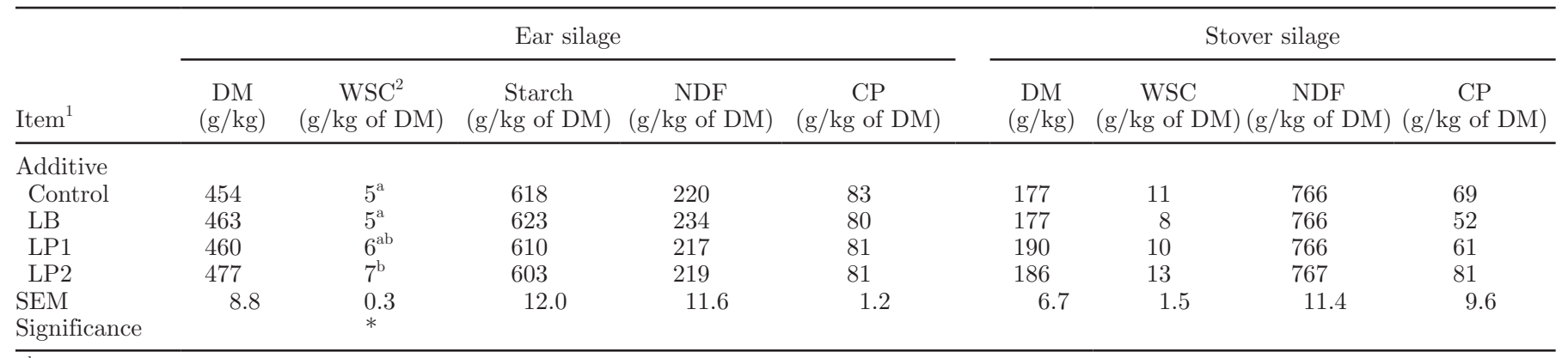

${ }_{\mathrm{a}, \mathrm{b}}$ Means within a column without a common superscript letter differ $(P<0.05)$.

${ }^{1}$ Contol $=$ uninoculated control; LB $=$ Lactobacillus buchneri 11A44; LP1 = Lactobacillus plantarum MTD-1; LP2 = L. plantarum 30114.

${ }^{2} \mathrm{WSC}=$ water-soluble carbohydrates.

${ }^{*} P<0.05$.

equivalents due to the probable detection of bacterial DNA from dead in addition to viable organisms.

\section{Aerobic Stability}

Aerobic stability was determined on samples taken after 130-d ensilage by placing approximately $2.7 \mathrm{~kg}$ of each silage into a polyethylene-lined polystyrene box (2.5-cm thick; $59 \mathrm{~cm} \times 39 \mathrm{~cm} \times 22 \mathrm{~cm})$, loosely covered with a polystyrene lid, and stored at $20^{\circ} \mathrm{C}$. Containers of water placed beside the boxes of silage were used to provide reference temperatures to which all silage temperatures were compared. A thermocouple was placed in the center of each silage sample and container of water. The temperatures were recorded on an hourly basis over 192-h period by a data logger (SQ ELTEK 80T; Eurolec Instrumentation Ltd., Dundalk, Ireland). The indices of aerobic stability and deterioration were expressed as 1) hours elapsed until the temperature rose more than $2^{\circ} \mathrm{C}$ higher above the reference temperature and 2) accumulated temperature rise above the reference temperature during 120-h exposure to air, respectively.

\section{Statistical Analysis}

Data to assess the nutritive value (e.g., DMD and starch), DM recovery, and aerobic stability and deterioration (i.e., d 130 only) in response to additive treatments were subjected to a 1-way ANOVA, whereas all other data were subjected to a 2-way ANOVA for a 4 (additive treatment) $\times 4$ (ensilage duration) factorial arrangement of treatments using the PROC GLM procedure of the SAS statistical program (SAS Institute, 2002). Treatment contrasts were made using the Fisher least significant differences test.

\section{RESULTS}

\section{Silage Nutritive Value (After 130-d Ensilage)}

The DM, NDF, and CP concentrations of ear and stover, and the starch concentration of ear only, after 130-d ensilage were unaffected $(P>0.05)$ by additive treatment (Table 4). The WSC concentration in ear silage was higher $(P<0.05)$ for $L$. plantarum 30114 (LP2) than for control or L. buchneri 11A44 (LB).

\section{Fermentation Products}

Inoculation of ears with LB, L. plantarum MTD-1 (LP1), or LP2 did not affect $(P>0.05)$ silage DM, lactic acid, acetic acid, ethanol, propionic acid, butyric acid, ammonia-N, or total fermentation product (TFP) concentrations for all ensilage durations, when compared with silages made from uninoculated ears (Table $5)$. Ear silages made with LB had a higher $(P<0.01)$ $\mathrm{pH}$ than all other treatments, and a higher $(P<0.05)$ acetic acid concentration and proportion of acetic acid in the TFP compared with ear silage made with LP1.

The concentrations of acetic acid, ethanol, and butyric acid were higher $(P<0.05)$ for the ear silages after 130-d ensilage compared with shorter ensiling durations, whereas lactic acid concentration was not affected $(P>0.05)$ by the duration of ensilage. Ear silages ensiled for $130 \mathrm{~d}$ had a lower $(P<0.001)$ proportion of lactic acid in the TFP and a higher $(P<$ 0.001) proportion of acetic acid in the TFP than silages ensiled for shorter durations.

The DM, acetic acid, butyric acid, and TFP concentrations of stover silages were unaffected $(P>0.05)$ by LB, LP1, or LP2 when compared with uninoculated silages (Table 6). Stover silages made with LB or LP2 and ensiled for $35 \mathrm{~d}$ had lower $(P<0.05)$ lactic acid 
Table 5. Fermentation products and microbial enumerations of corn ear silages made with different bacterial additives for 4 ensilage durations

\begin{tabular}{|c|c|c|c|c|c|c|c|c|c|c|c|c|c|c|c|c|c|c|c|c|}
\hline \multirow[b]{3}{*}{ Item } & \multicolumn{16}{|c|}{ Ensilage duration and additive ${ }^{1}$} & \multirow[b]{3}{*}{ SEM } & & & \\
\hline & \multicolumn{4}{|c|}{$3 \mathrm{~d}$} & \multicolumn{4}{|c|}{$10 \mathrm{~d}$} & \multicolumn{4}{|c|}{$35 \mathrm{~d}$} & \multicolumn{4}{|c|}{$130 \mathrm{~d}$} & & \multicolumn{3}{|c|}{ Significance $^{2}$} \\
\hline & $\mathrm{C}$ & LB & LP1 & LP2 & $\mathrm{C}$ & LB & LP1 & LP2 & $\mathrm{C}$ & LB & LP1 & LP2 & $\mathrm{C}$ & LB & LP1 & LP2 & & A & $\mathrm{E}$ & $\mathrm{A} \times \mathrm{E}$ \\
\hline $\mathrm{DM}(\mathrm{g} / \mathrm{kg})$ & 456 & 449 & 451 & 445 & 463 & 443 & 453 & 451 & 452 & 447 & 444 & 432 & 446 & 452 & 455 & 466 & 6.6 & & & \\
\hline $\mathrm{pH}$ & 3.8 & 4.1 & 3.9 & 3.9 & 3.9 & 3.9 & 3.8 & 3.7 & 3.8 & 4.0 & 3.8 & 3.7 & 3.9 & 4.1 & 3.8 & 3.7 & 0.10 & $* *$ & & \\
\hline Lactic acid (g/kg of DM) & 12 & 12 & 11 & 16 & 13 & 13 & 10 & 11 & 16 & 14 & 11 & 17 & 12 & 7 & 16 & 6 & 3.4 & & & \\
\hline Acetic acid (g/kg of DM) & 2.0 & 2.0 & 1.3 & 1.8 & 2.0 & 1.7 & 1.1 & 1.3 & 2.1 & 3.8 & 1.6 & 2.6 & 4.9 & 7.6 & 2.7 & 5.3 & 0.76 & $*$ & $* * *$ & \\
\hline Ethanol $(\mathrm{g} / \mathrm{kg}$ of $\mathrm{DM})$ & 1.1 & 1.4 & 1.2 & 1.1 & 2.7 & 2.2 & 1.8 & 1.8 & 3.1 & 2.9 & 4.0 & 2.9 & 5.3 & 5.4 & 5.0 & 3.7 & 0.46 & & *** & \\
\hline Propionic acid ( $\mathrm{g} / \mathrm{kg}$ of $\mathrm{DM})$ & 0.2 & 0.1 & 0.2 & 0.2 & 0.3 & 0.2 & 0.1 & 0.1 & 0.2 & 0.2 & 0.1 & 0.8 & 0.4 & 0.7 & 0.3 & 2.1 & 0.42 & & & \\
\hline Butyric acid (g/kg of DM) & 0.0 & 0.1 & 0.1 & 0.0 & 0.2 & 0.1 & 0.0 & 0.0 & 0.1 & 1.3 & 0.1 & 0.6 & 0.4 & 1.3 & 0.2 & 1.8 & 0.44 & & * & \\
\hline $\mathrm{TFP}^{3}(\mathrm{~g} / \mathrm{kg}$ of DM $)$ & 15 & 16 & 13 & 19 & 18 & 17 & 13 & 15 & 21 & 22 & 16 & 22 & 23 & 22 & 25 & 19 & 3.9 & & & \\
\hline $\mathrm{NH}_{3}-\mathrm{N}^{4}(\mathrm{~g} / \mathrm{kg}$ of $\mathrm{N})$ & & & & & & & & & & & & & 84 & 115 & 92 & 95 & 10.9 & & & \\
\hline $\begin{array}{l}\text { Lactic acid/TFP } \\
\text { (g of lactic acid/g of TFP) }\end{array}$ & 0.76 & 0.70 & 0.79 & 0.81 & 0.72 & 0.70 & 0.76 & 0.71 & 0.68 & 0.62 & 0.61 & 0.71 & 0.50 & 0.32 & 0.65 & 0.38 & 0.094 & & $* * *$ & \\
\hline $\begin{array}{l}\text { Acetic acid/TFP } \\
\text { (g of acetic acid/g of TFP) }\end{array}$ & 0.15 & 0.18 & 0.10 & 0.11 & 0.11 & 0.12 & 0.08 & 0.12 & 0.12 & 0.18 & 0.12 & 0.10 & 0.23 & 0.35 & 0.12 & 0.25 & 0.043 & $*$ & $* * *$ & \\
\hline LAB (plate count) ${ }^{5}$ & 8.21 & 8.68 & 8.81 & 8.96 & 8.02 & 8.69 & 8.28 & 8.42 & 8.02 & 8.50 & 7.55 & 7.00 & 7.92 & 7.81 & 7.45 & 6.48 & 0.321 & $*$ & $* * *$ & \\
\hline Lactobacillus buchneri $(\mathrm{qPCR})^{6}$ & 3.65 & 6.33 & 3.86 & 3.70 & 4.12 & 8.40 & 4.10 & 3.15 & 6.11 & 6.88 & 4.95 & 4.19 & 7.56 & 7.64 & 5.74 & 5.35 & 0.513 & $* * *$ & $* * *$ & $*$ \\
\hline Lactobacillus plantarum (qPCR) ${ }^{6}$ & 4.35 & 5.20 & 7.70 & 5.95 & 4.95 & 7.00 & 6.99 & 5.61 & 6.15 & 5.99 & 7.76 & 6.29 & 6.37 & 6.18 & 6.44 & 5.51 & 0.336 & $* * *$ & $*$ & $* *$ \\
\hline
\end{tabular}

${ }^{1} \mathrm{C}=$ uninoculated control; LB = Lactobacillus buchneri 11A44; LP1 = Lactobacillus plantarum MTD-1; LP2 = L. plantarum 30114.

${ }^{2} \mathrm{~A}=$ inoculant; $\mathrm{E}=$ ensiling period

${ }^{3} \mathrm{TFP}=$ total fermentation products (lactic acid + acetic acid + propionic acid + butyric acid + ethanol)

${ }^{4}$ Only analyzed after $130-d$ ensilage.

${ }^{5} \mathrm{LAB}=$ lactic acid bacteria; plate count $=\log _{10}$ (cfu using agar/g of herbage).

${ }^{6} \log _{10}$ (estimated cfu using real-time quantitative PCR/g of herbage).

${ }^{*} P<0.05,{ }^{* *} P<0.01,{ }^{* * *} P<0.001$. 
concentrations, lower $(P<0.01)$ proportions of lactic acid in the TFP, and higher $(P<0.01)$ proportions of acetic acid in the TFP when compared with uninoculated stover or stover inoculated with LP1. In addition, stover silages made with LB had a higher $(P<0.05)$ $\mathrm{pH}$ than silages made with either LP1 or LP2.

The acetic acid, ethanol, propionic acid, butyric acid, and TFP concentrations were higher $(P<0.001)$ and the lactic acid concentration lower $(P<0.001)$ for stover ensiled for $130 \mathrm{~d}$ compared with shorter ensilage durations. In addition, stover ensiled for $130 \mathrm{~d}$ had a lower $(P<0.01)$ proportion of lactic acid in the TFP and a higher $(P<0.01)$ proportion of acetic acid in the TFP compared with shorter ensilage durations.

\section{Microbiology}

The $\mathrm{qPCR}$ data revealed that $L$. buchneri populations were more abundant $(P<0.001)$ in uninoculated ear silages than in silages made using LP1 and LP2 after 35-d ensilage (Table 5). Although L. buchneri populations were higher $(P<0.01)$ after 35 -d ensilage in silages prepared using LB, no difference $(P>0.05)$ was observed between uninoculated and LB silages ensiled for the other ensilage durations. Ears ensiled with LP1 had higher $(P<0.01) L$. plantarum populations than other treatments after 3 - and 35 -d ensilage, whereas ear silages inoculated with LB had higher $(P<0.05)$ total LAB counts using plate count enumerations than those made using LP2.

Stover silages made with LB had higher $(P<0.01)$ L. buchneri populations and lower $(P<0.001)$ L. plantarum populations than uninoculated, LP1, or LP2 silages, whereas total LAB populations of stover silages were unaffected by additive treatment $(P>0.05)$. The $L$. plantarum population numbers of stover silages made with LP1 or LP2 did not differ $(P>0.05)$ from those of uninoculated control silages.

Populations of L. buchneri in ear and stover were more abundant $(P<0.01)$ after 130 -d ensilage than after shorter durations, whereas L. plantarum populations were more abundant $(P<0.05)$ after 35 -d ensilage compared with other ensiling durations. Total LAB numbers, analyzed using plate count enumerations, were higher $(P<0.001)$ for both ear and stover silages ensiled for either 3 or $10 \mathrm{~d}$ compared with longer durations.

\section{DM Recovery and Aerobic Stability (After 130-d Ensilage)}

The recovery of ensiled DM in ear and stover silages was unaffected $(P>0.05)$ by additive treatment (Table 7). Ear silages made with LB and ensiled for $130 \mathrm{~d}$ had a greater $(P<0.05)$ amount of time elapsed between initial exposure to air and a temperature rise of more than $2^{\circ} \mathrm{C}$ above the reference temperature and a lower $(P<0.05)$ accumulated temperature after 120 -h exposure to air when compared with silages made with LP1 or LP2 (Table 6). No additive effects were observed $(P>0.05)$ on the aerobic stability or deterioration of stover.

\section{DISCUSSION}

\section{Pre-Ensiled Herbage}

The DM concentrations of ear and stover at harvest were within the range of values previously reported for corn grown in similar conditions by Phipps and Weller $(1979 ; 299$ to $435 \mathrm{~g}$ of $\mathrm{DM} / \mathrm{kg}$ for fresh ear and 198 to $243 \mathrm{~g}$ of $\mathrm{DM} / \mathrm{kg}$ for fresh stem) and Little et al. (2007a,b; 185 to $590 \mathrm{~g}$ of DM / kg for fresh ear and 171 to $344 \mathrm{~g}$ of DM $/ \mathrm{kg}$ for fresh stover). However, the ears and stover were generally more immature and of a lower DM content than the range for herbages previously used by other researchers to study the ensilage of ear (i.e., high-moisture ear corn, 640 to $790 \mathrm{~g}$ of DM/kg for fresh ear corn; Faber et al., 1989; Phillip and Fellner, 1992; Taylor and Kung, 2002; Kung et al., 2007) or stover (300 to $680 \mathrm{~g}$ of DM/kg for fresh stover; Muck and Shinners, 2006; Muck et al., 2008; Sun et al., 2009).

\section{Uninoculated Control Silages}

Despite uninoculated ear silages generally undergoing restricted fermentations when compared with the corresponding stover silages, the fermentation was more extensive than previously reported for ears by Faber et al. (1989), Taylor and Kung (2002), and Kung et al. (2007), and reflected the lower DM concentration in the present study. The fermentation of uninoculated ear silages was predominantly homofermentative during the first $35 \mathrm{~d}$ of ensilage, whereas the fermentation had become more heterofermentative by $130 \mathrm{~d}$ of ensilage. This appears to have resulted from the secondary fermentation of lactic acid during the ensiling process. Some LAB and clostridial species can utilize lactic acid as a substrate anaerobically (Pahlow et al., 2003), and the low butyric acid and ammonia- $\mathrm{N}$ concentrations in the present study indicate that little clostridial activity occurred in these uninoculated silages. Therefore, the indigenous epiphytic L. buchneri population in the present study likely contributed to the decrease in the proportion of lactic acid in the TFP between 35 and $130 \mathrm{~d}$ of ensilage by degrading lactic acid to acetic acid and 1,2-propanediol (Oude Elferink et al., 2001). Driehuis et al. (2001) reported that L. buchneri 
Table 6. Fermentation products and microbial enumerations of corn stover silages made with different bacterial additives for 4 ensilage durations

\begin{tabular}{|c|c|c|c|c|c|c|c|c|c|c|c|c|c|c|c|c|c|c|c|c|}
\hline \multirow[b]{3}{*}{ Item } & \multicolumn{16}{|c|}{ Ensiling duration and additive ${ }^{1}$} & \multirow[b]{3}{*}{ SEM } & & & \\
\hline & \multicolumn{4}{|c|}{$3 \mathrm{~d}$} & \multicolumn{4}{|c|}{$10 \mathrm{~d}$} & \multicolumn{4}{|c|}{$35 \mathrm{~d}$} & \multicolumn{4}{|c|}{$130 \mathrm{~d}$} & & \multicolumn{3}{|c|}{ Significance $^{2}$} \\
\hline & $\mathrm{C}$ & $\mathrm{LB}$ & LP1 & LP2 & $\mathrm{C}$ & LB & LP1 & LP2 & $\mathrm{C}$ & LB & LP1 & LP2 & $\mathrm{C}$ & LB & LP1 & LP2 & & $\mathrm{A}$ & $\mathrm{E}$ & $\mathrm{A} \times \mathrm{E}$ \\
\hline $\mathrm{DM}(\mathrm{g} / \mathrm{kg})$ & 190 & 186 & 186 & 192 & 198 & 188 & 183 & 194 & 193 & 183 & 200 & 193 & 175 & 176 & 189 & 185 & 6.0 & & & \\
\hline $\mathrm{pH}$ & 4.1 & 4.5 & 3.9 & 3.8 & 3.9 & 3.9 & 3.9 & 3.9 & 4.0 & 4.4 & 3.7 & 4.0 & 4.6 & 4.6 & 4.4 & 4.5 & 0.17 & * & $* * *$ & \\
\hline Lactic acid ( $\mathrm{g} / \mathrm{kg}$ of $\mathrm{DM})$ & 25 & 17 & 18 & 16 & 31 & 24 & 25 & 21 & 27 & 12 & 43 & 14 & 1 & 0 & 3 & 1 & 9.2 & * & $* * *$ & \\
\hline Acetic acid $(\mathrm{g} / \mathrm{kg}$ of $\mathrm{DM})$ & 10 & 7 & 9 & 8 & 12 & 12 & 13 & 14 & 19 & 27 & 17 & 26 & 46 & 43 & 44 & 43 & 2.3 & & $* * *$ & \\
\hline Ethanol ( $\mathrm{g} / \mathrm{kg}$ of $\mathrm{DM})$ & 6 & 5 & 5 & 5 & 7 & 8 & 6 & 6 & 11 & 15 & 10 & 11 & 28 & 29 & 33 & 25 & 1.0 & * & $* * *$ & ** \\
\hline Propionic acid ( $\mathrm{g} / \mathrm{kg}$ of $\mathrm{DM})$ & 0.5 & 0.4 & 0.5 & 0.2 & 0.3 & 0.9 & 0.9 & 1.0 & 1.8 & 3.3 & 0.8 & 2.7 & 3.5 & 4.5 & 6.3 & 3.5 & 0.41 & & $* * *$ & ** \\
\hline Butyric acid $(\mathrm{g} / \mathrm{kg}$ of $\mathrm{DM})$ & 0.1 & 0.0 & 0.0 & 0.0 & 0.1 & 0.6 & 0.3 & 0.4 & 0.1 & 0.2 & 0.0 & 0.6 & 0.5 & 1.3 & 0.5 & 0.3 & 0.27 & & * & \\
\hline $\mathrm{TFP}^{3}(\mathrm{~g} / \mathrm{kg}$ of $\mathrm{DM})$ & 42 & 30 & 33 & 29 & 51 & 45 & 45 & 42 & 59 & 57 & 71 & 54 & 80 & 78 & 87 & 72 & 9.7 & & $* * *$ & \\
\hline $\mathrm{NH}_{3}-\mathrm{N}^{4}(\mathrm{~g} / \mathrm{kg}$ of $\mathrm{N})$ & & & & & & & & & & 01 & r & & 97 & 102 & 71 & 76 & 12.2 & & & \\
\hline $\begin{array}{l}\text { Lactic acid/TFP } \\
\text { ( } \mathrm{g} \text { of lactic acid/g of TFP) }\end{array}$ & 0.59 & $9 \quad 0.57$ & 0.53 & 0.53 & 0.60 & 0.49 & 0.51 & 0.51 & 0.47 & 0.21 & 0.60 & 0.21 & 0.02 & 0.01 & 0.04 & 0.01 & 0.042 & $* *$ & $* * *$ & ** \\
\hline $\begin{array}{l}\text { Acetic acid/TFP } \\
\text { (g of acetic acid/g of TFP) }\end{array}$ & 0.25 & $5 \quad 0.22$ & 0.28 & 0.28 & 0.25 & 0.29 & 0.32 & 0.32 & 0.32 & 0.47 & 0.24 & 0.52 & 0.58 & 0.54 & 0.51 & 0.59 & 0.029 & $* *$ & $* * *$ & $* *$ \\
\hline LAB (plate count) ${ }^{5}$ & 8.46 & $6 \quad 8.78$ & 8.92 & 9.54 & 8.43 & 8.56 & 8.46 & 9.02 & 8.02 & 8.66 & 7.74 & 7.56 & 8.15 & 8.09 & 8.15 & 8.31 & 0.203 & & $* * *$ & * \\
\hline Lactobacillus buchneri (qPCR) ${ }^{6}$ & 4.64 & $4 \quad 5.69$ & 3.79 & 4.37 & 4.85 & 5.27 & 4.12 & 3.78 & 5.31 & 7.34 & 5.57 & 4.89 & 6.03 & 6.96 & 6.57 & 7.07 & 0.497 & ** & $* * *$ & \\
\hline Lactobacillus plantarum (qPCR) ${ }^{6}$ & 6.27 & $7 \quad 5.30$ & 6.90 & 6.15 & 6.48 & 5.19 & 6.96 & 5.97 & 6.50 & 7.00 & 7.09 & 6.98 & 6.16 & 6.03 & 6.37 & 6.79 & 0.254 & $* * *$ & $* *$ & $*$ \\
\hline
\end{tabular}

thoctic acid + butyric acid + ethanol)

${ }^{4}$ Only analyzed after 130-d ensilage.

${ }^{5} \mathrm{LAB}=$ lactic acid bacteria; plate count $=\log _{10}$ (cfu using agar/g of herbage).

$\quad{ }^{6} \log _{10}$ (estimated cfu using real-time quantitative PCR/g of herbage) 
Table 7. Effect of additive on DM recovery, aerobic stability, and deterioration of corn ears and stover after 130-d ensilage

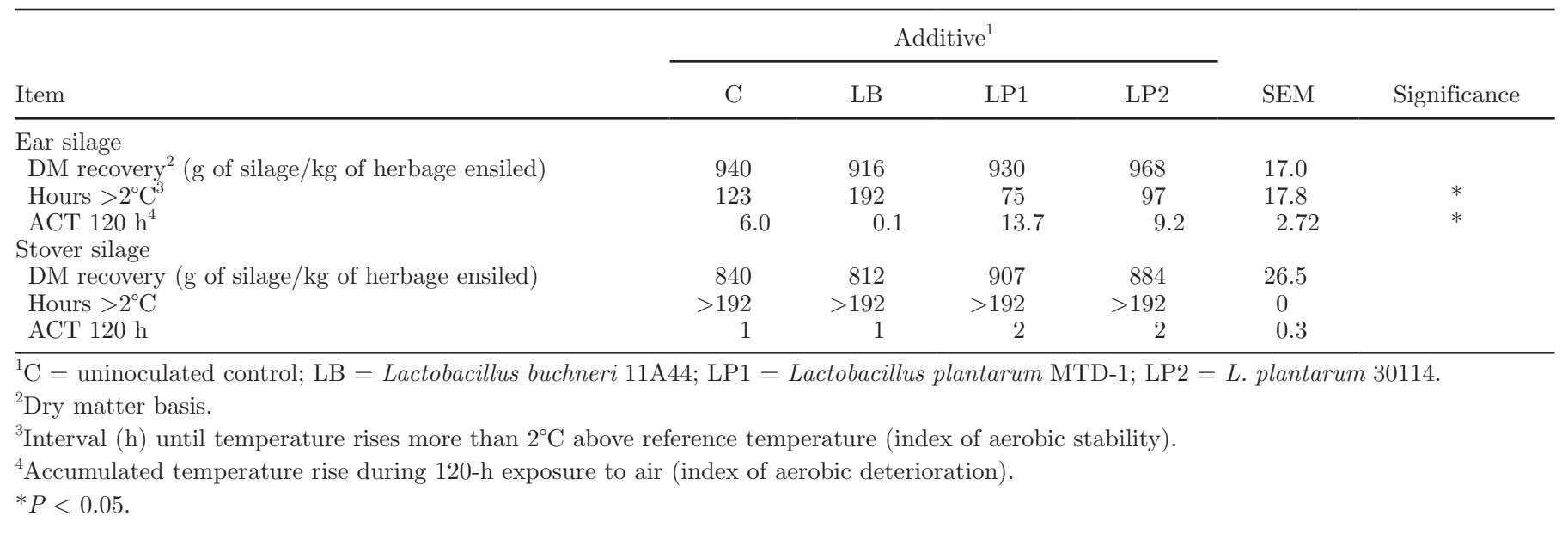

in whole-crop corn silage was unable to compete with other LAB populations during the primary phase of fermentation, but became predominant during the later stages of fermentation and was still active after $218 \mathrm{~d}$ of ensilage. The resulting high acetic acid concentration of uninoculated ear silages resulted in a relatively stable silage on exposure to air. This disagrees with Taylor and Kung (2002) and Kung et al. (2007) who reported low aerobic stability of high-moisture ear corn ensiled for $166 \mathrm{~d}$.

The more extensive fermentation of stover silages in the present study when compared with the ear silages was likely due to lower DM concentrations of the pre-ensiled herbage, in addition to a higher buffering capacity. The fermentation of stover was more heterofermentative after 3-, 10-, and 35-d ensilage durations than occurred with the ear fraction. Similarly, Muck and Shinners (2006) and Shinners et al. (2007) reported increased heterolactic fermentations for stover silages when DM content at ensiling decreased to $300 \mathrm{~g} / \mathrm{kg}$. However, the lactic acid concentration of uninoculated stover silages in the present study was greatly decreased when ensilage continued for $130 \mathrm{~d}$. Muck and Shinners (2006) stated that the secondary fermentation of lactic acid by epiphytic L. buchneri likely contributed to the heterolactic nature of relatively immature (300 g of DM/kg) stover silage fermentations. Similar to ear silages, L. buchneri populations were high in uninoculated stover silages in the present study and following the 130-d ensilage, it appears that lactic acid concentrations were almost exhausted as a substrate. This finding is supported by the corresponding large increase in acetic acid concentrations between 35 and $130 \mathrm{~d}$ of ensilage. Uninoculated stover silages had a lower DM recovery than ear silages, likely due to a lower DM concentration at ensiling, increasing effluent production (Hameleers et al., 1999), and the more het- erolactic fermentation, increasing DM loss through gas production (McDonald et al., 1991). The uninoculated stover silages were aerobically very stable, as evidenced by the lack of increase in their temperatures during the 192-h assessment period.

\section{L. buchneri 11A44 Inoculation}

The lack of an effect of the LB treatment on the fermentation and aerobic stability of ear silages when compared with the uninoculated silages was in contrast to Taylor and Kung (2002) and Kung et al. (2007) who reported increased acetic acid concentrations and improved aerobic stability for high-moisture corn silage made with L. buchneri and ensiled for 166 and $120 \mathrm{~d}$, respectively. The different results in the present study may reflect the high epiphytic populations of $L$. buchneri on the pre-ensiled ear. Lactobacillus buchneri populations were only higher for ear silages made with LB after 3- and 10-d ensilage compared with uninoculated silages, but no difference was observed between these silages after 35- or 130-d ensilage, and it is in this late stage of ensilage that $L$. buchneri actively affects the silage fermentation process (Driehuis et al., 2001).

The higher proportion of acetic acid and lower proportion of lactic acid in the TFP and the higher $L$. buchneri numbers in stover silages made with LB and ensiled for $35 \mathrm{~d}$, compared with uninoculated silages, was in accord with Muck and Shinners (2006) who reported increased acetic acid concentrations for corn stover silage made with L. buchneri. However, no difference was observed in the present study after 130-d ensilage between stover silages made with LB or without additive application, due to a similar exhaustion of lactic acid in these silages. Furthermore, the lack of difference in the fermentation characteristics between stover silages made with LB or without additive and 
ensiled for 130 d likely contributed to their similar DM recovery values and their high aerobic stability.

\section{L. plantarum MTD-1 Inoculation}

Despite LP1 increasing the numbers of $L$. plantarum on ears after 3 and $35 \mathrm{~d}$ of ensilage and correspondingly, decreasing the number of L. buchneri after 130 $\mathrm{d}$ of ensilage compared with uninoculated silages, the fermentation characteristics of these 2 silages did not differ. This disagrees with Faber et al. (1989) who reported that the ensilage of ear corn with an $L$. plantarum-based inoculant ultimately increased the lactic acid concentration of the silage. The lower $L$. buchneri numbers and acetic acid concentration for ear silages made with LP1, in comparison with the LB silages, contributed to poorer aerobic stability and increased aerobic deterioration of LP1 silages. This likely reflected the lower concentration of acetic acid providing less inhibition of yeast (Woolford, 1975), the main organisms responsible for the initiation of aerobic deterioration (Danner, 2003). Similar detrimental effects on the aerobic stability of whole-crop corn made with $L$. plantarum based inoculants have been reported by Filya (2003) and Filya and Sucu (2010).

The lack of difference between the fermentation dynamics, DM recovery, or aerobic stability of stover silages made with LP1 and without additive disagrees with Muck et al. (2008) who reported increased lactic acid and ethanol concentrations and decreased acetic acid concentration in stover silage made with an $L$. plantarum-based inoculant. The lack of effect of the LP1 treatment was related to it not having an effect on L. plantarum numbers, compared with the uninoculated silages, indicating that added LAB failed to successfully dominate the fermentation. The higher proportion of lactic acid in the TFP of LP1-treated stover for 35-d ensilage, compared with silages made with LB, was in accord with Filya (2003) and Filya and Sucu (2010). However, in the present study, no differences in the fermentation characteristics, DM recovery, and aerobic stability were observed between these treatments after 130-d ensilage, likely due to the extensive secondary fermentation of lactic acid in a similar manner to what occurred with uninoculated stover silages

\section{L. plantarum 30114 Inoculation}

The fermentation characteristics, DM recovery, and aerobic stability of ear silages made with LP2 were similar to uninoculated silages and silages made with LB. However, the lower proportion of lactic acid in the TFP of silages made with LP2, compared with LP1, indicated contrasting effects of these different strains of the same species. The decrease in $L$. buchneri numbers in ear silages made with LP2 compared with no additive indicates that the use of LP2 altered their microbial profile. However, it is not possible to conclude that L. plantarum 30114 was a dominant organism in these silages, as L. plantarum numbers were generally lower than or similar to uninoculated silages. In addition, stover silages made with LP2 had a higher proportion of acetic acid in the TFP than did silage made without an additive or silages made with LP1, but did not differ from the LB treatment after 35-d ensilage. In contrast to the present study, Ranjit and Kung (2000) reported improved aerobic stability of whole-crop corn silage made with L. plantarum 30114 compared with an uninoculated control. Therefore, the contrasting fermentation characteristics of silages inoculated with L. plantarum MTD-1 and L. plantarum 30114 warrant further investigation.

\section{CONCLUSIONS}

The nutritive value, aerobic stability, and DM recovery of ear and stover silages in this study were not improved by inoculation at ensiling with $L$. buchneri 11A44, L. plantarum MTD-1, or L. plantarum 30114, compared with an uninoculated control. This was due to the highly heterolactic secondary fermentation that dominated the later stages of the 130-d ensilage process in all treatments, which was promoted by some of the indigenous epiphytic microflora. The fermentation of stover silages tended to be more extensive and heterolactic than ear silages for all ensilage durations. The differences that were observed in the fermentation profile of silages made following inoculation with L. plantarum MTD-1 or L. plantarum 30114 warrant further investigation.

\section{ACKNOWLEDGMENTS}

Funding for this study was provided under the National Development Plan through the Research Stimulus Fund administered by the Department of Agriculture, Fisheries and Food (RSF 07 501). The provision of corn seed by Seed Technology Ltd. (Ballymountain, Ferrybank, Waterford, Ireland), the input in crop production and ensilage by B. Weldon (Teagasc) and Teagasc Grange farm staff and the chemical and molecular analyses by Teagasc Grange laboratory staff and M. McCabe (Teagasc) are acknowledged.

\section{REFERENCES}

AOAC. 1990. Official Methods of Analysis. First supplement to the 15th edition. Method 990-03. Association of Official Analytical Chemists, Arlington, VA.

Journal of Dairy Science Vol. 95 No. 4, 2012 
Danner, H., M. Holzer, E. Mayrhuber, and R. Braun. 2003. Acetic acid increases stability of silage under aerobic conditions. Appl. Environ. Microbiol. 69:562-567.

Driehuis, F., S. J. W. H. Oude Elferink, and P. G. Van Wikselaar. 2001. Fermentation characteristics and aerobic stability of grass silage inoculated with Lactobacillus buchneri, with or without homofermentative lactic acid bacteria. Grass Forage Sci. 56:330-343.

Faber, D. A., J. G. Linn, and D. E. Otterby. 1989. Effect of a bacterial inoculant on the fermentation of high moisture shelled and ear corn. J. Dairy Sci. 72:1234-1242.

Filya, I. 2003. The effect of Lactobacillus buchneri and Lactobacillus plantarum on the fermentation, aerobic stability, and ruminal degradability of low dry matter corn and sorghum silages. J. Dairy Sci. 86:3575-3581

Filya, I., and E. Sucu. 2010. The effects of lactic acid bacteria on the fermentation, aerobic stability and nutritive value of maize silage. Grass Forage Sci. 65:446-455.

Hameleers, A., K. A. Leach, N. W. Offer, and D. J. Roberts. 1999. The effects of incorporating sugar beet pulp with forage maize at ensiling on silage fermentation and effluent output using drum silos. Grass Forage Sci. 54:322-335.

Hu, W., R. J. Schmidt, E. E. McDonell, C. M. Klingerman, and L. Kung Jr. 2009. The effect of Lactobacillus buchneri 40788 or Lactobacillus plantarum MTD-1 on the fermentation and aerobic stability of corn silages ensiled at two dry matter contents. J. Dairy Sci. 92:3907-3914

Klocke, M., K. Mundt, C. Idler, J. McEniry, P. O'Kiely, and S. Barth. 2006. Monitoring Lactobacillus plantarum in grass silages with the aid of $16 \mathrm{~S}$ rDNA-based quantitative real-time PCR assays. Syst. Appl. Microbiol. 29:49-58.

Kung, L., Jr., R. J. Schmidt, T. E. Ebling, and W. Hu. 2007. The effect of Lactobacillus buchneri 40788 on the fermentation and aerobic stability of ground and whole high-moisture corn. J. Dairy Sci. 90:2309-2314

Little, E. M., P. O'Kiely, J. C. Crowley, and G. P. Keane. 2007a. Cob development in forage maize: Interaction of harvest date, plastic mulch and cultivar. Page 98 in Proc. Agricultural Research Forum, Tullamore, Ireland. Standard Printers, Galway, Ireland.

Little, E. M., P. O'Kiely, J. C. Crowley, and G. P. Keane. 2007b. Stover development in forage maize: Interaction of harvest date, plastic mulch and cultivar. Page 97 in Proc. Agricultural Research Forum, Tullamore, Ireland. Standard Printers, Galway, Ireland.

McCleary, B. V., V. Solah, and T. S. Gibson. 1994. Quantitative measurement of total starch in cereal flours and products. J. Cereal Sci. 20:51-58.

McDonald, P., A. R. Henderson, and S. J. R. Heron. 1991. The Biochemistry of Silage. Chalcombe publications, Bucks, UK.

Muck, R. E. 2010. Silage microbiology and its control through additives. R. Bras. Zootec. 39:183-191.

Muck, R. E., J. G. Coors, T. L. Richard, and M. P. Scott. 2008. Effect of treatment and cultivar on the ensiling of corn stover. Paper no. 085001 in Proc. ASABE Annu. Int. Mtg. American Society of Agricultural and Biological Engineers, Providence, RI

Muck, R. E., and K. Shinners. 2006. Effect of inoculants on the ensiling of corn stover. Paper no. 061013 in Proc. ASABE Annu. Int. Mtg. American Society of Agricultural and Biological Engineers, Portland, OR

O'Kiely, P., and R. K. Wilson. 1991. Comparison of three silo types used to study in-silo processes. Isr. J. Agric. Res. 30:53-60.

Oude Elferink, S. J. W. H., J. Krooneman, J. C. Gottschal, S. F. Spoelstra, F. Faber, and F. Driehuis. 2001. Anaerobic conversion of lactic acid to acetic acid and 1,2-propanediol by Lactobacillus buchneri. Appl. Environ. Microbiol. 67:125-132.
Pahlow, G., R. E. Muck, F. Driehuis, S. J. W. H. Oude Elferink, and S. F. Spoelstra. 2003. Microbiology of ensiling. Pages 31-93 in Silage Science and Technology. D. R. Buxton, R. E. Muck, and J. H. Harrison, ed. American Society of Agronomy, Madison, WI.

Phillip, L. E., and V. Fellner. 1992. Effects of bacterial inoculation of high-moisture ear corn on its aerobic stability, digestion, and utilization for growth by beef steers. J. Anim. Sci. 70:3178-3187.

Phillip, L. E., H. J. Garino, I. Alli, and B. E. Baker. 1985. Effects of anhydrous ammonia on amino acid preservation and feeding value of high-moisture ear corn for growing steers. Can. J. Anim. Sci. $65: 411-417$.

Phipps, R. H., and R. F. Weller. 1979. The development of plant components and their effects on the composition of fresh and ensiled forage maize: 1 . The accumulation of dry matter, chemical composition and nutritive value of fresh maize. J. Agric. Sci. $92: 471-483$.

Playne, M. J., and P. McDonald. 1966. The buffering constituents of herbage and of silage. J. Sci. Food Agric. 17:264-268.

Porter, M. G., and R. S. Murray. 2001. The volatility of components of grass silage on oven drying and the inter-relationship between drymatter content estimated by different analytical methods. Grass Forage Sci. 56:405-411.

Ranfft, K. 1973. Determination by gas chromatography of short-chain volatile fatty acids in ruminal fluids. Arch. Tierernahr. 23:343352.

Ranjit, N. K., and L. Kung Jr. 2000. The effect of Lactobacillus buchneri, Lactobacillus plantarum, or a chemical preservative on the fermentation and aerobic stability of corn silage. J. Dairy Sci. $83: 526-535$.

SAS Institute. 2002. SAS/STAT User's Guide. Version 9.1. SAS Institute Inc., Cary, NC.

Schmidt, R. J., M. G. Emara, and L. Kung Jr. 2008. The use of a quantitative real-time polymerase chain reaction assay for identification and enumeration of Lactobacillus buchneri in silage. J. Appl. Microbiol. 105:920-929.

Schmidt, R. J., and L. Kung Jr. 2010. The effects of Lactobacillus buchneri with or without a homolactic bacterium on the fermentation and aerobic stability of corn silages made at different locations. J. Dairy Sci. 93:1616-1624.

Shinners, K. J., B. N. Binversie, R. E. Muck, and P. J. Weimer. 2007. Comparison of wet and dry corn stover harvest and storage. Biomass Bioenergy 31:211-221.

Sun, Z. H., S. M. Liu, G. O. Tayo, S. X. Tang, Z. L. Tan, B. Lin, Z X. He, X. F. Hang, Z. S. Zhou, and M. Wang. 2009. Effects of cellulase or lactic acid bacteria on silage fermentation and in vitro gas production of several morphological fractions of maize stover. Anim. Feed Sci. Technol. 152:219-231.

Taylor, C. C., and L. Kung Jr. 2002. The effect of Lactobacillus buchneri 40788 on the fermentation and aerobic stability of high moisture corn in laboratory silos. J. Dairy Sci. 85:1526-1532.

Thomas, T. A. 1977. An automated procedure for the determination of soluble carbohydrates in herbage. J. Sci. Food Agric. 28:639-642.

Tilley, J. M. A., and R. A. Terry. 1963. A two-stage technique for the in vitro digestion of forage crops. J. Br. Grassl. Soc. 18:104-111.

Van Soest, P. J., J. B. Robertson, and B. A. Lewis. 1991. Methods for dietary fiber, neutral detergent fiber and nonstarch polysaccharides in relation to animal nutrition. J. Dairy Sci. 74:3583-3597.

Woolford, M. K. 1975. Microbiological screening of food preservatives, cold sterilants and specific antimicrobial agents as potential silage additives. J. Sci. Food Agric. 26:229-237. 